Ярошевич Ирина Наумовна, доцент, Ангарский государственный технический университет, e-mail: sport@angtu.ru

ОПРЕДЕЛЕНИЕ ФИЗИЧЕСКОЙ РАБОТОСПОСОБНОСТИ СТУДЕНТОВ

Yaroshevich I.N.

\title{
DETERMINATION OF PHYSICAL PERFORMANCE STUDENTS
}

\begin{abstract}
Аннотация. Рассмотрен анализ физической работоспособности студенческой молодежи АнГТУ при помощи функциональных проб Руффьье и Гарвардского степ-теста для изучения общей выносливости.

Ключевые слова: фризическое развитие, общая выносливость, физическая нагрузка, функциональная проба Руффье, Гарвардский степ-тест.

Abstract. The analysis of the work of the physical performance of the students of AnGTU with the help of functional tests of Ruffier for the study of general endurance and the Harvard step test is considered.
\end{abstract}

Keywords: Physical development, general endurance, physical activity, Ruffier functional test, Harvard step test.

Для того чтобы студенты больше и эффрективней занимались фризической культурой и спортом в период обучения в университете, необходимо при организации занятий учитывать, чего они ждут от практических занятий, какую пользу из них хотят извлечь для себя лично.

При изучении нашей темы ключевым направлением все чаще становится определение фризической работоспособности студентов.

В ходе педагогического эксперимента была изучена общая выносливость студенческой молодежи при помощи функциональных проб Руффье и Гарвардского степ-теста. В эксперименте принимали участие две группы: первая группа в количестве 11 человек занималась физкультурой 2 раза в неделю по 1,30 часа, вторая группа спортивного совершенствования по легкой атлетике в количестве 10 человек занималась 3 раза в неделю по 1,30 часа.

Используемая функциональная проба Руфффье имеет широкое применение в спортивной практике. Последовательность работы заключалась в следующем: у студентов стоя измеряли ЧСС (частота сердечных сокращений) за 15 с (P1), затем они выполняли 30 глубоких приседаний, после нагрузки сразу подсчитывали чСС (частота сердечных сокращений) за первые 15 с (P2); а потом - за последние 15 с (Р3) [2].

Рассчитывали пробу по формуле:

$$
\text { Индекс Руфффье }=(\mathrm{P} 2-70)+(\mathrm{P} 3-\mathrm{P} 1) / 10
$$

Используемая функциональная проба позволила определить общую выносливость студентов. Объединение в пробе фризических нагрузок неодинаковой направленности характеризует адаптацию организма к различным видам работы, что весьма важно для контроля [1]. 
Полученный в результате эксперимента материал дает возможность сравнения результатов обеих групп. У первой группы результат расценивается как средний, с диапазоном величин от 3 до 5, вторая группа имеет существенные различия, результат 2,9 считается хорошим.

Следующим методом является Гарвардский степ-тест, который также служит для определения физической работоспособности студенческой молодежи и не требует специальной аппаратуры [1].

Выполнялся этот тест путем восхождения на ступеньку 30 раз в минуту. Частота движений устанавливалась на 120 уд/мин. Высота ступени составляла $50 \mathrm{~cm}$, время восхождения - 5 минут, фриксировали секундомером.

После выполненной работы у студентов замерли ЧСС (частота сердечных сокращений) в течение первых 30 с на 2, 3 и 4 мин. восстановления. Рассчитывали по формуле:

ИГСТ = $\mathrm{t}$ время восхождения 5 мин $\times 100 /$ сумма пульса, подсчитываемого в течение первых 30 с на 2, 3 и 4 мин. восстановления $x 2$.

Преимущественный результат показала вторая группа - 82 (оценивается как хороший результат), первая группа показала средний результат - 67 .

После теста восстановление у ребят составляло 5 мин, после чего мы им замеряли артериальное давление, у первой группы АД - 127/85 мм.рт.ст; вторая группа АД - 118/80 мм.рт.ст.

В заключение работы хочется отметить, что восстановление у обеих экспериментальных групп хорошее, но результаты имеют некоторые различия. Нетрудно заметить, что у второй группы контрольные показатели значительно лучше, это говорит о более высоком уровне физической работоспособности студентов, занимающихся в группе спортивного совершенствования по легкой атлетике.

\section{ЛИТЕРАТУРА}

1. Адаптация и здоровье: учебное пособие / Э.М. Казин [и др]; под ред. Э.М. Казина. - Кемерово: Кузбассвузиздат, 2003.

2. Ярошевич И.Н. Общая физическая и специальная подготовка в системе физического воспитания в ВУЗе: методическое пособие / И.Н. Ярошевич. - Ангарск: АГТА, 2002. -84 c. 